\title{
MEMAKNAI PERILAKU MUSLIM DALAM BERSEDEKAH (Studi Fenomenologi Pengalaman Muzakki LAGZIS Sabilit Taqwa Bululawang)
}

\author{
Sutikno \\ Fakultas Ekonomi Universitas Trunojoyo Madura \\ Jl. Raya Telang, Kecamatan Kamal, Kabupaten Bangkalan, Madura 16912 \\ Email: tikno_fe_utm_@yahoo.com/HP: 08123203044
}

Umar Burhan

Moh. Khusaini

Khusnul Ashar

Fakultas Ekonomi Universitas Brawijaya

Jl. Veteran Malang 65145 Indonesia

\begin{abstract}
The purposes of the study are: 1) Giving sense to what does motivate people to spent his money for goodness toward sedekah, 2) Giving sense to the kind of reply both in form of profit or satisfaction which earned by people from sedekah. 3) Giving sense to the process of someone who's got better life by sedekah. The research findings are: (1) Informant's motivation in sedekah. First is emotional power, it's a kind of sympathy feeling when there are suffering people around. Second is spiritual power that means an understanding of religion precept. Third is empiric power, it's like personal experiences and parents got replied from sedekah. (2) Informants got replied by sedekah, first in form of healthiness and avoided from calamity. This healthiness is made from happiness and calm feeling when making others happy. Second, is in form of success and profit on work. The third is in form of ten times replied or more than sedekah. 3) Informant experiences showed that sedekah is developing our faith and believe to Allah SWT. Our faith and believe were manifest on two things. First, it makes us closer with our maker Allah SWT. This experience was happened on all informants. All of them feel their extensity in this world (being-in-the world) perceivable as together with the existence of Allah SWT. Second, sedekah (almsgiving) brings the informants to better life attitude, such as honest, professionalism and hard worker.
\end{abstract}

Key words: Sedekah, Phenomenology, Consumption, Welfare.

Pola konsumsi masyarakat pada masa kini lebih menekankan pada aspek pemenuhan keinginan material dari pada aspek kebutuhan yang lain. Amat sedikit sekali perhatian yang diberikan untuk memenuhi kebutuhan kemanusiaan, hakikat dan kualitas barang dan jasa yang diproduksi untuk memenuhi kebutuhan ini dan bagaimana hal itu dapat didistribusikan secara lebih adil kepada semua anggota masyarakat. Bahkan rasionalitas konsumen hanya dipandang dari sisi bagaimana ia mamaksimalkan nilai guna dengan usaha yang paling minimal. Hal ini tentu saja menjadikan seluruh mesin produksi diarahkan secara langsung maupun tidak langsung untuk memenuhi tujuan ini dengan 
mengabaikan apakah pemenuhan keinginan ini pada hakekatnya akan meningkatkan kesejahteraan manusia secara hakiki atau bukan (Basri, 2004).

Tulisan Thorstein Veblen pada masa 1857-1929 juga mengemukakan, dalam teorinya tentang konsumsi yang menyolok, bahwa sesuatu di samping keinginan-keinginan individual yang tersusun secara acak menentukan sifat permintaan. Orang-orang yang sangat kaya, menurut Veblen, memilih pola-pola pengeluaran mereka untuk menekankan, melambangkan, dan membangun posisi kelas mereka, agar berbeda dengan masyarakat lainnya. Di sini Veblen melihat bahwa konsumsi sebagai suatu "Social phenomenon", Veblen melihat bahwa "leisure class" (masyarakat kelas atas) mempengaruhi masyarakat "taste” mereka. Studi-studi sosiologi yang mengamati masalah ini antara lain: Weber, Mause, Keynes dan Douglass. Studi Douglass (1979) mendiskripsikan bahwa: Konsumsi merupakan media komunikasi, khususnya dalam menentukan identitas seseorang dan posisi sosial.

Meskipun sebagian besar ada masyarakat yang melakukan perilaku konsumsi atau pengeluaran harta sesuai dengan kepentingan dan kepuasan diri sendiri serta menjelaskan identitas sosialnya, manun ada sebagian masyarakat yang membelanjakan hartanya untuk kepentingan orang lain atau untuk kepentingan kemanusiaan. Beberapa fakta ditunjukkan dari hasil penelitian berikut ini.

Penelitian yang berkaitan dengan sedekah atau pengeluaran harta pernah dilakukan oleh Ross Gittell and Edinaldo Tebaldi yang berjudul "Charitable Giving: Factors Influencing Giving in U.S. States". Penelitian ini mendiskripsikan bahwa pemberian (amal sedekah) yang diberikan oleh rumah tangga di Amerika Serikat adalah cukup signifikan besarnya. Lebih dari dua per tiga dari semua rumah tangga melaporkan bahwa mereka melakukan amal sedekah (Hodgkinson, Nelson dan Sivak, 1996). Amal sedekah oleh swasta (private giving) menempati lebih dari tiga per empat dari semua amal sedekah, dan nilainya mencapai lebih dari 2 persen dari total PDB (GDP) dan ini merupakan sebuah faktor yang signifikan di dalam mendanai sektor nirlaba di dalam perekonomian Amerika Serikat, di mana sektor nirlaba ini menempati lebih dari 10 persen dari PDB (American Association of Fundraising Counsel [AAFRC], 2003).

Hasil penelitian ini mendapatkan temuan yang mengkonfirmasi temuan-temuan dari penelitian-penelitian sebelumnya mengenai dampak dari faktor ekonomi, demografis dan sosiologis terhadap amal sedekah di berbagai negara bagian di Amerika Serikat. Kontribusi utama dari catatan penelitian ini adalah terletak pada data dan analisa terinci 
yang disajikan di dalamnya, yang menghasilkan temuan yang mendukung dan melengkapi penelitian-penelitian sebelumnya yang telah mengidentifikasi bahwa faktor-faktor utama yang mempengaruhi amal sedekah oleh rumah tangga adalah pendapatan personal, keuntungan kapital, afiliasi dengan kelompok religius tertentu, usia, keinginan untuk menjadi relawan (volunteerism) dan level pendidikan. Sebagian besar dari temuan dari catatan penelitian kami ini konsisten dengan penelitian-penelitian sebelumnya yang dilakukan pada level nasional (seperti Clotfelter, 2002; Deb, Wilhelm, Rooney dan Brown, 2003).

Penelitian lain yang berkaitan dengan faktor-faktor yang berpengaruh terhadap pemberian atau sedekah adalah penelitian yang dilakukan oleh Patricia Hughes and William Luksetich yang berjudul "Income Volatility and Wealth: The Effect on Charitable Giving”. Hasil penelitian ini menunjukkan bahwa, pendapatan permanen keluarga memiliki efek yang positif kuat dan signifikan secara statistik terhadap total amal sedekah keluarga. Elastisitas dari amal sedekah untuk pendapatan permanen keluarga adalah setara dengan 1,75. Ini mengimplikasikan bahwa peningkatan sebesar 10 persen pada pendapatan permanen keluarga akan meningkatkan amal sedekah sebesar 17,5 persen. Peningkatan variasi pada pendapatan keluarga memiliki dampak yang negatif dan signifikan terhadap amal sedekah, sehingga memberikan dukungan terhadap hipotesa bahwa ketidakpastian yang lebih besar mengurangi amal sedekah. Sesuai dengan hipotesa semula, efek dari perubahan pada pendapatan sementara adalah tidak signifikan.

Berangkat dari dua fenomena di atas yang bersifat kontradiktif, di mana pada satu sisi ada sebagian besar masyarakat yang membelanjakan hartanya untuk kepentingan dan kepuasan pribadi. Sementara di sisi lain dari hasil beberapa penelitian menunjukkan bahwa ada sekelompok masyarakat yang membelanjakan hartanya untuk kepentingan orang lain atau sosial. Dua fenomena yang kontras inilah yang menarik perhatian peneliti untuk mengkaji lebih dalam pola pengeluaran harta dari sekelompok masyarakat yang membelanjakan hartanya untuk kepentingan orang lain yang berakar dari konsep Islam.

Berangkat dari latar belakang di atas, maka penelitian ini mempunyai tujuan sebagai berikut: (1) Memaknai apa yang menjadi motivasi seseorang mengeluarkan hartanya melalui sedekah; (2) Memaknai bentuk balasan yang berupa kepuasan atau keuntungan yang diperoleh seseorang yang mengeluarkan hartanya melalui sedekah. Dan (3) Memaknai proses seseorang yang mengamalkan bersedekah menuju tingkat kesejahteraan yang lebih baik. 


\section{METODE}

Penelitian ini akan cenderung menggunakan pendekatan logika induktif, di mana sologisme dibangun berdasarkan pada hal-hal khusus atau data di lapangan dan bermuara pada kesimpulan-kesimpulan umum. Pendekatan ini umumnya tidak digunakan sebagai alat mencari data dalam arti frekwensi akan tetapi digunakan untuk menganalisis proses sosial yang berlangsung dan makna dari fakta-fakta yang tampak dipermukaan tersebut. Dengan demikian, maka analisis dalam pendekatan ini digunakan untuk memahami sebuah proses dan fakta dan bukan sekedar untuk menjelaskan fakta tersebut.

Berdasarkan pada paradigma ilmu pengetahuan dan ilmu sosial serta permasalahan yang ingin dijawab pada penelitian ini, membawa konsekuensi pada pemilihan pendekatan penelitian. Penelitian ini menggunakan pendekatan kualitatif, dengan alasan pendekatan kualitatif dapat digunakan untuk melihat realitas yang dalam hal ini tidak sekadar sebuah hasil, tetapi bagaimana proses berlangsung dan realitas-realitas lain yang melingkupi proses itu. Pendekatan kualitatif pada dasarnya sangat tekun dalam posisi filosofis, di mana kebanyakan imterpretivis memberi perhatian kepada bagaimana dunia sosial diinterpretasi, dimengerti, dialami atau dihasilkan (Mason, 1996).

Latar penelitian ini adalah berupa proses sosial yang terjadi dalam masyarakat yang mengeluarkan harta berdasarkan konsep Islam, melalui zakat, infaq, shadakah, dan wakaf. Obyek dari penelitian ini adalah meningkatnya antusias masyarakat atau orang untuk mengeluarkan hartanya di jalan Allah (kedermawanan) melalui zakat, infaq, shadakah, dan wakaf akan dikaji secara mendalam terutama para dermawan yang melakukan kedermawanannya secara terus menerus (istiqamah). Sedangkan yang menjadi subyek dalam penelitian ini adalah para pelaku (orang) yang secara langsung terlibat di dalam realitas yang diamati, terutama yang berkaitan dengan persepsi, motivasi dan keuntungan/manfaat yang diperoleh dari kedermawanannya.

Sample atau informan dalam penelitian kualitatif (dikenal sebagai internal sampling), tidak digunakan dalam usaha untuk melakukan generalisasi statistik atau sekedar mewakili populasinya, tetapi lebih mengarah kepada generalisasi teoritis. Sumber data yang dipergunakan di sini tidak untuk mewakili populasinya, tetapi cenderung mewakili informasinya, dengan kelengkapan dan kedalamannya yang tidak sangat perlu ditentukan oleh jumlah sumber datanya (Bikeln dalam Sutopo, 2002).

Dalam penelitian ini, karena penentuan sample atau informan juga mengacu kepada kedalaman informasinya, maka metode penentuan informan yang digunakan adalah 
purposive sampling (metode penentuan sample yang dilakukan secara sengaja atau metode sampling dengan berbagai alasan atau tujuan). Karena penelitian ini didesain berdasarkan pendekatan kualitatif verifikatif, jadi untuk menjaga konsistensi penelitian ini, maka strategi analisis datanya juga akan menggunakan strategi analisis data kualitatif-verifikatif. Strategi analisis data kualitatif-verifikatif merupakan sebuah upaya analisis induktif terhadap data penelitian yang dilakukan pada seluruh proses penelitian yang dilakukan, karena itu, format strategi analisis data penelitiannya secara total berbeda dengan format penelitian kuantitatif.

Format penelitian kualitatif-verivikatif mengkonstruksi format penelitian dan strategi untuk lebih awal memperoleh data sebanyak-banyaknya di lapangan, dengan mengesampingkan peran teori, walaupun demikian, teori bukanlah sesuatu yang tidak penting dalam format ini. Tujuan analisis dari penelitian ini lebih mengarah pada analisis makna yang ada dibalik informasi, data, dan proses suatu fenomena sosial. Berdasarkan tujuan tersebut, maka metode analisis data yang dipakai dalam penelitian ini adalah kelompok analisis kinerja dan pengalaman individu, serta perilaku institusi. Berdasarkan tujuan dan kelompok metode analisis, maka penelitian ini akan menggunakan beberapa metode analisis data, di antaranya: 1) Analisis Life History, 2) Studi Kasus, dan 3) Focus Group Discussion (FGD).

\section{PEMBAHASAN}

Sintesa yang bisa di rumuskan dari aktivitas kebiasaan sedekah informan ada tiga yaitu: Pertama, ketidakmampuan materi bukan menjadi halangan bagi informan untuk bersedekah. Si Petani bersedekah dengan cara membuatkan "gedeg" untuk orang yang tidak mampu beli. Demikian pula si pensiunan dengan tenaga, fikiran dan waktu beliau bisa memberdayakan kaum lansia dan memajukan pendidikan masyarakat di sekitarnya.

Kedua, dalam bersedekah informan melakukannya secara ikhlas dan secara terusmenerus atau istiqamah. Sintesa ini dibangun berdasarkan pengalaman si karyawan swasta dan Si PNS yang memberi mungkin hanya sebesar Rp. 1000 sampai Rp. 2000 per hari atau Si Pensiunan yang setiap hari memberi secangkir kopi untuk pemulung. Hal tersebut merupakan manifestasi dari rasa empati mereka terhadap kondisi sosial masyarakat di sekitarnya dan tidak mempunyai niatan yang lain kecuali ibadah dan rasa kasih sayang terhadap sesamanya. 
Ketiga, informan "mendidik" dirinya untuk meningkatkan dan mengistiqamahkan sedekahnya. Sintesa ini dibangun berdasarakan pengalaman Si Tukang bakso yang melakukan sedekah rutin setiap menjelang lebaran kepada tukang becak dan orang miskin. Si Pensiunan yang secara terus menerus menanggung biaya listrik dan air di masjid sekitar rumahnya. Si Petani mewariskan kebiasaanya kepada anaknya meskipun sudah di Amerika dan Hongkong, sementara si PNS selalu menyiapkan uang di mobilnya untuk beramal di jalan dan mewajibkan dirinya untuk sedekah setiap hari, sedangkan si karyawan swasta mendisiplinkan diri untuk menyisakan $2.5 \%$ pendapatannya untuk sedekah sebelum masuk rumah.

Fenomena kebiasan sedekah yang dilakukan informan yang berusaha untuk melakukannya secara terus menerus dan mengeluarkannya lebih banyak terhadap orang lain memberikan pembuktian bahwa tidak semua aktivitas mengkonsumsi barang/jasa yang dilakukan oleh seseorang bertujuan untuk dinikmati sendiri. Informan yang kami teliti, melakukan aktivitas konsumsi selain bertujuan untuk memuaskan diri sendiri, juga bertujuan untuk memuaskan kepentingan orang lain, yaitu dengan cara bersedekah.

Berdasarakan sintesa yang dibanguan oleh fenomena kebiasaan sedekah informan dan teori konsumsi yang menyatakan hukum penurunan utilitas marginal (law of diminising marginal utility), maka kami merumuskan proposisi pertama dari kebiasaan sedekah informan dapat dirumuskan sebagai berikut: "Aktivitas konsumsi yang bertujuan untuk memuaskan diri sendiri dan untuk memuaskan orang lain, yaitu dengan cara bersedekah akan menyebabkan tidak berlakukanya law of diminishing marginal utility”.

Fenomena pengalaman sedekah memberikan kontribusi teori dengan pernyataan bahwa "aktivitas sedekah atau mengkonsumsi barang/jasa untuk tidak dinikmati sendiri, tapi disebar untuk orang lain, maka konsumen tersebut tidak mengalami yang disebut law of diminishing marginal utility”. Hal ini disebabkan karena berbeda dengan kepuasan yang bersifat individualis, mashlahah dari sedekah tidak hanya bisa dirasakan oleh individu. Mashlahah bisa jadi dirasakan oleh konsumen yang lain, yaitu dirasakan oleh sekelompok masyarakat seperti tukang becak dan orang miskin. Dalam kasus si tukang bakso yang membeli kaos dan kemudian diberikan kepada tukang becak dan tetangga miskin yang ada di daerahnya, maka mashlahah fisik/psikis akan dinikmati oleh tetangga yang diberi kaos dan uang, sementara itu, si tukang becak akan mendapatkan berkah. Dengan demikian selama orang miskin masih ada, maka para dermawan tidak akan pernah puas yang dia lakukan. Pertanyaannya apakah mungkin orang miskin itu tidak di muka bumi ini? 
jawabannya tentunya tidak mungkin. Apabila tidak mungkin orang miskin tidak ada di muka bumi ini, tidak mungkin pula law of diminishing marginal utility sedekah berlaku pada orang-orang dermawan.

\section{Motivasi Sedekah}

Sintesa yang bisa di rumuskan dari fenomena motivasi sedekah informan ada tiga yaitu: pertama ada kekuatan emosional yang mereka rasakan dalam memotivasi mereka sedekah, yaitu perasaan merasakan kesedihan jika ada orang lain yang ada di sekitarnya merasa sedih atau susah. Sebaliknya, mereka merasakan kebahagiaan jika mereka bisa memberikan kesenangan atau kebahagiaan terhadap orang ada di sekitarnya. Motivasi itulah yang lebih dominan yang dirasakan oleh si petani dan pensiunan, dalam bersedekah di samping pemahaman agama.

Sintesa kedua, ada kekuatan spiritual yang lebih dominan yang memotivasi responden untuk bersedekah. Fenomena ini seperti yang dirasakan oleh si tukang bakso dan PNS, beliau merasakan lebih dimotivasi oleh dorongan spiritual, terutama berkaitan dengan pemahaman beliau berdua terhadap konsep harta. Si tukang bakso menganggap harta berasal dari Allah dan mengeluarkan harus sesuai dengan yang dikehendaki Allah yaitu melalui sedekah. Sementara si PNS menganggap bahwa harta yang hakiki adalah harta yang kita berikan kepada orang lain.

Sintesa ketiga, ada kekuatan empirik yang lebih dominan yang memotivasi informan untuk bersedekah. Fenomena ini dirasakan oleh si karyawan swasta, beliau merasakan lebih dimotivasi oleh pengalaman-pengalaman orang tua dan keluarga yang mendapatkan kesuksesan dan kebahagian hidup karena mengamalkan sedekah.

Berdasarkan sintesa yang dibanguan oleh fenomena motivasi sedekah informan dan teori pola konsumsi yang menyatakan faktor yang mempengaruhi konsumsi adalah faktor sosisl, ekonomi, dan lingkungan, maka kami merumuskan proposisi dari motivasi sedekah informan sebagai berikut: "motivasi informan dalam membelanjakan hartanya selain dipengaruhi oleh faktor ekonomi, sosial, dan budaya, juga dipengaruhi oleh faktor ketaatan mengamalkan ajaran agama."

Berdasarkan ulasan di atas, maka proposisi yang didasari oleh temuan penelitian ini, selain memberikan kontribusi terhadap teori pola konsumsi. Berdasarkan teori ekonomi konvensional hanya ada tiga faktor, yaitu ekonomi, sosial, dan budaya, penelitian ini memberikan kontribusi tambahan faktor agama yang berpengaruh pula pada pola konsusmi 
masyarakat. Konstribusi selanjutnya dari proposisi di atas adalah, mengkritik paradigma Adam Smith yang menyatakan bahwa kemerdekaan (freedom), kebebasan alamiah (natural liberty), dan hukum-hukum moral (moral laws) adalah kunci terbangunnya epistemologi ekonomi yang memimpin tingkah laku manusia. Tiga faktor tersebut yang akan menjaga keseimbangan perilaku manusia, atau bisa disebut sebagai keseimbangan kosmik. Keseimbangan kosmik yang dimaksud itu adalah kebebasan, kebahagiaan, dan keharmonisan yang lahir pada individu, masyarakat, dan negara. Keseimbangan kosmik ditentukan oleh kehadiran invisible hand manakala manusia itu tunduk pada aturan-aturan moral.

Paradigma tersebut di atas yang dikritik dari hasil penelitian ini, penelitian ini menunjukkan bahwa kebahagian dan keharmonisan dalam inidividu, masyarakat dan negara, tidak ditentukan oleh kehadiran invisible hand, artinya tidak datang secara alamiah, akan tetapi ada campur tangan Tuhan, yaitu melalui ajaran agama, dalam konteks penelitian ini adalah sedekah. Sedekah yang bisa menjadi instrumen untuk distribusi pendapatan, sehingga tercipta kesejahteraan dan keharmonisan dalam masyarakat terjadi bukan karena faktor alamiah, tetapi terjadi karena faktor perintah agama. Dengan demikian faktor agama masih memegang peranan penting dalam membangun moral pelaku ekonomi dan masih menjadi sumber hukum moral tertinggi dalam kehidupan bermasyarakat untuk menjaga keharmonisan dan kesejahteraan.

\section{Balasan Sedekah}

Sintesa yang bisa di rumuskan dari fenomena balasan sedekah informan ada tiga yaitu: Pertama, balasan sedekah dirasakan dalam bentuk kesehatan dan terhindar dari musibah, kesehatan ini terbentuk karena perasaan si pemberi selalu senang dan tenang ketika bisa menyenangkan orang lain. Itulah yang dialami oleh si petani, pensiunan, dan tukang bakso. Sintesa kedua, balasan sedekah dirasakan dalam bentuk kesuksesan usaha dan tambahan penghasilan seperti yang dirasakan oleh si tukang bakso. Sintesa ketiga, balasan sedekah dirasakan dalam bentuk balasan 10 kali lipat bahkan lebih, itulah yang dirasakan oleh si pensiunan, si PNS, dan si karyawan swasta. Untuk memaknai sintesa dan dalam upaya membangun proposisi, maka sintesa yang berkaitan dengan balasan sedekah informan, akan kita lihat dari perspektif dalil-dalil dan hasil penelitian ilmiah yang menjelaskan tentang sintesa-sintesa di atas. 
Sintesa pertama, yang menyatakan bahwa informan merasakan balasan sedekah dalam bentuk kesehatan dan terhindar dari musibah, sintesa tersebut dibuktikan oleh beberapa hasil penelitian yang kesimpulannya bahwa, orang yang senang memberi atau berbuat baik terhadap orang lain akan merasakan aliran gairah euforia yang diikuti dengan periode rasa tenang dan bahagia. Perasaan yang disebut "Luks Helper's High" ini melibatkan sensasi-sensasi yang sangat kuat yang mengindikasikan adanya penurunan tingkat stres dan melepaskan pembunuh rasa sakit alamiah dalam tubuh yang disebut endorfin. Menolong orang lain, merupakan cara terbaik mempertebal rasa (sense) percaya dan menambah kekuatan perlindungan tubuh melawan penyakit. Berangkat dari sintesa yang didasari dari fenomena pengalaman informan dalam merasakan balasan sedekah dan kemudian didukung oleh hasil-hasil penelitian, maka rasanya tidak berlebihan jika kami mengajukan proposisi bahwa "sedekah sebagai konsep alternatif "asuransi kesehatan dan musibah".

Sintesa kedua dan ketiga merupakan sintesa yang mengarah pada kesamaan manfaat dari balasan sedekah yaitu peningkatan pendapatan, oleh sebab itu untuk memaknai sintesa kedua dan ketiga akan menggunakan konsep teori yang sama. Untuk menerangkan balasan sedekah yang bisa meningkatkan pendapatan atau penghasilan, kami menggunakan konsep konsep manajer investasi (wealth manager). Berdasarkan hasil kajian, menunjukkkan bahwa setidaknya ada empat perbedaan antara manajer investasi di lembaga penyedia wealth management atau investment management dengan sedekah, yaitu: a) Jumlah keuntungan yang ditawarkan; b) Prosedur investasi; c) Jaminan keuntungan; dan d) Tingkat realistisnya.

Tabel 3.1

Perbedaan Investment Management Dengan Sedekah

\begin{tabular}{|c|c|c|c|c|}
\hline No & Perbedaan & $\begin{array}{c}\text { Investment } \\
\text { Management }\end{array}$ & Sedekah & Dialami informan \\
\hline 1 & $\begin{array}{l}\text { Jumlah } \\
\text { keuntungan } \\
\text { yang } \\
\text { ditawarkan }\end{array}$ & $\begin{array}{l}\text { Rendah, } \\
\text { biasanya } \\
\text { maksimal 10\%. }\end{array}$ & $\begin{array}{l}\text { Tinggi, minimal } 10 \\
\text { kali lipat dari dana yg } \\
\text { diinvestasikan di jalan } \\
\text { Allah. } \\
\text { (QS: 2:261) (QS: } \\
6: 160)\end{array}$ & $\begin{array}{l}\text { Pensiunan: 67-69; } \\
\text { 74-76 } \\
\text { PNS: 6-7; 51-52 } \\
\text { Swasta: 196-197 }\end{array}$ \\
\hline 2 & $\begin{array}{l}\text { Prosedur } \\
\text { Investasi }\end{array}$ & Sulit dan rumit & $\begin{array}{l}\text { Mudah dan sederhana } \\
\text { (QS: 65: 7) }\end{array}$ & $\begin{array}{l}\text { Swasta: } 53-58 \\
\text { PNS: } 3-6 \\
\text { Pensiunan: 112- } \\
113\end{array}$ \\
\hline
\end{tabular}




\begin{tabular}{|c|l|l|l|l|}
\hline 3 & $\begin{array}{l}\text { Jaminan } \\
\text { keuntungan }\end{array}$ & $\begin{array}{l}\text { Tidak ada } \\
\text { jaminan } \\
\text { mendapat. } \\
\text { keuntungan }\end{array}$ & $\begin{array}{l}\text { Ada jaminan } \\
\text { mendapat keuntungan } \\
\text { (QS: 35:29) }\end{array}$ & $\begin{array}{l}\text { Tukang Bakso: 54- } \\
56 \\
\text { Swasta 196-197 }\end{array}$ \\
\hline 4 & $\begin{array}{l}\text { Tingkat } \\
\text { realistisnya }\end{array}$ & Harus realistis & Tidak harus realistis & $\begin{array}{l}\text { PNS: 67-70 } \\
\text { Petani: 134-136 } \\
\text { Swasta: 95-97 }\end{array}$ \\
\hline
\end{tabular}

Berangkat dari sintesa yang didasari fenomena pengalaman informan dalam merasakan balasan sedekah dan kemudian didukung oleh dalil-dalil Al Quran, serta konsep wealth management atau investment management, maka rasanya tidak berlebihan jika kami mengajukan proposisi bahwa "sedekah bisa dijadikan sebagai wealth manager (manajer investasi) alternatif", dalam upaya meningkatkan pendapatan masyarakat.

Dengan demikian proposisi ini memberikan kontribusi terhadap teori ekonomi kesejahteraan (welfare economics) khususnya dalam aspek ekonomi terapan (applied economics) yaitu sedekah bisa dijadikan sebagai intrumen dalam teori kebijakan ekonomi alternatif (theory of economic policy) untuk meningkatkan kesejahteraan masyarakat khusus dalam aspek kesehatan dan peningkatan indeks harapan hidup, yang menjadi salah satu indikator pengukuran kesejahteraan masyarakat yang biasa disebut dengan istilah Indeks Pembangunan Manusia atau Human Development Index (HDI).

\section{Sedekah dan Transmisi Menuju Sejahtera}

Sintesa yang bisa di rumuskan dari fenomena transformasi spritual dan perubahan perilaku hidup informan ada dua yaitu: Pertama, sedekah menghantarkan informan merasakan eksistensi keberadaan mereka di dunia (being-in-the world) dipahami sebagai keberadaan bersama Allah (being-with-God). Kedua, sedekah menghantarkan informan merasakan perbaikan perilaku hidup seperti kejujuran, profesionalisme dan etos kerja tinggi.

Untuk memaknai sintesa dan adalam upaya membangun proposisi, maka sintesa yang berkaitan dengan perubahan perilaku hidup informan, akan kita lihat dari perspektif dalil-dalil, konsep teoritis dan hasil penelitian ilmiah yang menjelaskan tentang sintesasintesa di atas. Sintesa pertama, yang menyatakan sedekah menghantarkan informan merasakan eksistensi keberadaan mereka di dunia (being-in-the world) dipahami sebagai keberadaan bersama Allah (being-with-God) berdasarkan pada fenomena pengalaman informan yang merasakan adanya transformasi spritual yang ditandai dengan 
meningkatnya keimanan dan ketaqwaan terhadap Allah SWT. Sintesa tersebut dibuktikan oleh bebera dalil dan hasil penelitian, beberapa ayat telah memberikan pemahaman kepada kita bahwa sedekah mengantarkan orang yang mengamalkannya menjadi orang yang beriman dan bertaqwa dan orang mengamalkan sedekah juga merupakan ciri dari orang yang beriman dan bertaqwa.

Sementara secara teoritis fenomena-fenomena yang muncul dalam proses tranformasi spritual informan ternyata sesuai dengan sejumlah karakteristik "kehidupan religius yang sudah matang (mature) sebagaimana dijelaskan oleh Allport (1950) dan dikembangkan Clark (1958). Ciri-ciri tersebut antara lain: terdiferensiasi, dinamis, konsisten, komprehensif, heuristik, integral dan mengalami hubungan keterdekatan secara langsung dengan Tuhan. Karakteristik terdiferensiasi dengan baik dari kehidupan religius informan ditunjukkan oleh pengalaman religius yang mencakup seluruh dimensi eksistensi informan, yaitu dimensi rasional, emosional, sosial, dan mistikal.

Karakter dinamis kehidupan religius yang matang ditunjukkan pada peran amalan sedekah yang mampu meningkatkan kehidupan beragama informan dan merestrukturisasi pandangan mereka terhadap dunia/harta, seperti harta berasal dari Allah dan harus digunakan sesuai dengan apa yang diperintahkan Allah. Konsistensi kehidupan religius informan ditunjukkan dengan munculnya perasaan menjadi seorang muslim sejati dan penerapan nilai-nilai moral Islam di dalam kehidupan sehari-hari. Karakteristik komprehensif terefleksi dalam peran yang jelas dirasakan dari agama Islam dalam memberi informan arah bagi kehidupan mereka. Pemahaman langsung mengenai Allah terungkap di dalam hubungan dekat informan dengan Allah yang ditandai dengan hilangnya egosentrisme terutama dalam kepemilikan harta.

Jadi secara teoritis, penelitian ini menunjukkan bahwa informan yang mengamalkan sedekah secara ikhlas dan istiqamah mengalami transformasi religius dari kehidupan religius "orang kebanyakan" menjadi kehidupan beragama yang bersifat "mististransendental". Hal itu bisa juga dikatakan bahwa kehidupan beragama informan berkembang dari kehidupan religius yang tidak matang menuju yang lebih matang. Atau dapat pula digambarkan adanya perubahan dari keyakinan imitatif menuju keyakinan intuitif. Dalam bahasa agama disebutkan sebagai perubahan dari keyakinan berdasarkan ilmu (ilmul yaqin) menuju keyakinan yang berdasarkan pengalaman (haqqul yaqin). Akhirnya bisa dijelaskan bahwa informan mengalami perubahan dari pemahaman diri sebagai seorang muslim, dari seorang muslim yang hidup untuk mencari kebahagian 
sendiri menjadi "berada-bersama-muslim-lain" (being-with-other-moslem) serta menuju pemahaman "berada-bersama-Allah" (being with God).

Kesadaran memberi kepada orang lain agar merasakan kebahagian seperti apa yang kita rasakan itulah yang disebut dengan kesadaran perduli dan empati terhadap penderitaan orang lain dan menjalankan perintah Allah, hal itulah yang kemudian disebut dengan kecerdasan emosional dan spiritual (emotional spritual quotient). Beberapa hasil penelitian tentang kecerdasan emosi dan spritual menunjukkan bahwa kecerdasan emosional dan sprituallah (seperti yang dirasakan informan) yang lebih berpengaruh terhadap kesuksesan hidup dan kesejahteraan.

Berangkat dari sintesa yang didasari fenomena pengalaman informan dalam merasakan adanya transformasi spiritual dan kemudian didukung oleh dalil-dalil Al Quran serta teori, maka rasanya tidak berlebihan jika kami mengajukan proposisi bahwa "sedekah menjadi instrumen untuk meningkatkan kesejahteraan lahir dan batin melalui transmisi iman dan taqwa". Sintesa kedua, yang menyatakan sedekah menghantarkan informan merasakan perbaikan perilaku hidup, yang ditandai dengan meningkatnya kejujuran, profesionalisme dan etos kerja tinggi, dibangun berdasarkan pada fenomena pengalaman informan yang merasakan adanya transformasi spiritual yang ditandai dengan meningkatnya perbaikan perilaku hidupnya sehari-hari.

Dalam upaya memberikan pembuktian bahwa sintesa tersebut bisa diterima secara rasional, kami kembali akan berangkat dari kata kunci iman dan taqwa. Karena peningkatan kejujuran, profesional, dan etos kerja tinggi sebesarnya merupakan manifestasi dari peningkatan keimanan dan ketaqwaan informan yang disebabkan oleh amalan sedekah yang ikhlas dan istiqamah.

Bagaimana keimanan dan ketaqwaan bisa memanifestasi seseorang untuk menjadi berperilaku menjadi baik? kami mencoba untuk menjawab dan membahas secara mendalam suatu pertanyaan tersebut dengan konsep “mental Building-enam Prinsip” yang diperkenalkan oleh Ary Ginanjar dalam bukunya yang berjudul: "Rahasia Sukses Membangun Kecerdasan Emosi dan Spritual Berdasarkan Enam Rukun Iman dan Lima Rukun Islam”. Dalam konsep ini menjelaskan bahwa keimanan akan membangun mental seseorang berdasarkan enam prinsip rukun iman yaitu 1) Star Princile; 2) Angel Principle; 3) Leadersip Principle; 4) Learning Principle; 5) Vision Principle; dan 6) Well Organized Principle. 
Dalam buku tersebut penulisnya mengajak kepada kita bahwa rukun iman bukan hanya dipercayai bahwa Allah itu ada, bahwa malaikat itu ada, bahwa nabi dan rasul itu ada, bahwa kitab itu ada, bahwa hari akhir atau kiamat itu ada, dan qadla' dan qadar (takdir Allah) itu ada. Tapi harus difahami dan diamalkan apa yang tersembunyi di balik enam rukun iman tadi. Kalau kita percaya kepada Allah, berarti kita harus memahami sifat-sifat Allah dan mengamalkan sebagai hamba-Nya (bukan sebagai Tuhan), itulah yang disebut pengamalan Star Princile. Jika kita beriman kepada Malaikat, kita harus memahami dan meneladani sifat-sifat malaikat, itulah yang disebut pengamalan Angel Principle; jika beriman kepada Nabi dan Rasul, kita harus memahami dan meneladani sifat-sifat Nabi dan Rasul itulah yang disebut pengamalan Leadersip Principle; jika beriman kepada kitabkitab Allah, kita harus pelajari dan amalkan, itulah yang disebut pengamalan Learning Principle; jika percaya pada hari akhir (kiamat) kita harus mempunyai visi hidup yang sesuai dengan visi atau tujuan Allah yang menciptakan kita, yaitu kebahagian dunia dan akhirat, itulah yang disebut pengamalan Vision Principle; jika kita beriman pada qadla' dan qadar (ketetapan Allah), maka kita harus menselaraskan hidup kita sesuai denga ketepan Allah (sunah tullah), itulah yang disebut pengamalan Well Organized Principle.

Jika kita mampu mengamalkan keenam prinsip tsebut, maka itulah bentuk keimanan yang paripurna dari seorang muslim sejati dan keimanan yang paripurnah itulah yang mengantarkan kita pada kebahagian dan kesejahteraan yang hakiki, karena dibangun oleh sifat-sifat mulia seperti jujur, profesional, dan etos kerja tinggi seperti yang dialami informan. Berangkat dari sintesa yang didasari fenomena pengalaman informan dalam merasakan adanya transformasi spiritual dan kemudian didukung oleh teori yang berkaitan dengan pemaknaan tersebut, maka rasanya tidak berlebihan jika kami mengajukan proposisi bahwa "sedekah menjadi intrumen meningkatkan kesejahteraan melalui transmisi perbaikan perilaku hidup informan terutama kejujuran, profesionalisme dan etos kerja tinggi"

Penelitian ini menjelaskan bahwa hukum-hukum moral tidak hanya bisa dibangun dengan konsep berfikir dari produk rasionalitas. Konsep sedekah yang bisa mengantarkan "pelakunya" menjadi sejahtera selain merupakan hasil berfikir selain merupakan produk rasionalitas, juga merupakan hasil berfikir transendental. Dengan kata lain, sedekah sebagai hukum moral, yang bersumber dari ajaran agama tidak semuanya bisa dijelaskan dengan cara berfikir rasional, tapi ada juga bersifat transendental yang terkadang sulit difahami secara nalar, namun secara empirik bisa terjadi. Hal tersebut terjadi karena ada 
keterbatasan manusia untuk merasionalkan kehendak-kehendak Allah; siapa hamba-Nya yang Dia kehendaki untuk sejahtera dan hamba-Nya yang tidak dikehendaki untuk sejahtera.

Kolaborasi antara rasionalitas dan transendental itulah yang menjadikan semakin meningkatnya kepercayaan manusia (keimanan) terhadap keberadaan Tuhan dalam mengatur kehidupannya. Keimanan itulah yang kemudian menjadi kekuatan besar untuk mengendalikan perilku hidup manusia menuju tingkat moralitas yang tinggi. Yang didalam bahasa agamanya disebut manusia yang berakhlak, baik berakhlak pada Allah, pada sesama manusia, dan alam semesta. Dengan akhlak inilah kemudian menjadikan dirinya menjadi mahluk yang tidak hanya sejahtera, tapi juga makhluk paling mulia di muka bumi ini. Dengan demikian agama masih menjadi intrumen utama untuk membangun moral manusia, namun sayang didalam epistimologi pemikiran Adam Smith, faktor agama dianggap tidak relevan, karena ajaran agama tidak semuanya bisa dirasionalkan dalam membangun moral dan membangun masyarakat modern.

Jadi moralitas tidak hanya bisa dibangun dari hasil berfikir rasional saja, namun butuh ajaran atau tuntunan agama yang kadang ada unsur transendentalnya. Jadi kontribusi teoritis dari hasil penelitan ini adalah sedekah yang bersumber dari ajaran agama Islam, masih relevan untuk memahami dan mengatasi permasalahan-permasalahan socioeconomy masyarakat, khususnya masalah kesejahteraan.

\section{Proposisi Minor Dan Mayor}

Proposisi mayor yang dimaksud dalam bahasan berikut ini adalah merupakan penarikan "benang merah" dari implikasi proposisi minor yang sudah dibahas pada subbab sebelumnya. Proposisi minor yang berhasil dirumuskan dalam memaknai kebiasaan sedekah yang dilakukan oleh informan ada dua yaitu: "aktivitas konsumsi yang bertujuan untuk memuaskan diri sendiri dan untuk memuaskan orang lain, yaitu dengan cara bersedekah akan menyebabkan tidak akan berlakukanya law of diminishing marginal utility”.

Proposisi di atas mengandung pengertian bahwa seorang konsumen yang bersedekah tidak akan mengalami titik jenuh dalam membelanjakan hartanya, karena mereka membelanjakan hartanya selain untuk memenuhi kepuasan sendiri, juga membagi kepuasannya untuk orang lain. Selama masih ada orang yang menginginkan kepuasan dari harta yang kita sedekahkan, maka kita tidak akan pernah puas dalam bersedekah. Oleh 
sebab itu, seseorang yang selalu istiqomah dalam bersedekah selalu ingin menambah jumlah sedekahnya. Dengan demikian kebiasaan membelanjakan harta dengan sedekah memberikan implakasi terjedinya kesejahteraan, pertama terhadap pemberi sedekah akan mendapatkan kepuasan hakiki baik secara lahir maupun batin. Karena selain bisa membahagiakan dirinya, juga bisa membahagiakan orang lain. Kedua, sedekah juga memberikan implikasi terhadap terjadinya distribusi kepuasan yang nantinya mengarah kepada kesejahteraan sosial (social welfare).

Proposisi yang berhasil dirumuskan dari fenomena motivasi sedekah informan yaitu "motivasi informan dalam membelanjakan hartanya selain dipengaruhi oleh faktor ekonomi, sosial, dan budaya, juga dipengaruhi oleh faktor ketaatan mengamalkan ajaran agama”. Implikasi dari proposisi ini adalah menyadarkan kita bahwa ajaran agama (sedekah) masih merupakan instrumen paling kuat untuk membangun moral dan etika yang baik terutama dalam aktivitas konsumsi. Dengan adanya moral dan etika dalam konsumsi maka, motivasi seseorang dalam membelanjakan hartanya tidak semata-mata hanya untuk mementingkan kepentingan pribadi tapi juga kepentingan sosial. Kondisi inilah yang nantinya akan mencegah terjadinya kecemburuan sosial yang berujung pada konflik sosial. Dengan demikian, implikasi dari motivasi membelanjakan harta karena faktor agama, sebagai "jaring pengaman konflik sosial” untuk menuju kesejahteraan yang berkelanjutan (sutainable welfare).

Proposisi minor yang berhasil dirumuskan dari balasan sedekah yang dirasakan informan antara lain. Pertama, "sedekah sebagai konsep alternatif "asuransi kesehatan dan musibah". Kedua, "sedekah bisa dijadikan sebagai wealth manager (manajer investasi) alternatif", dalam upaya meningkatkan pendapatan masyarakat. Kedua proposisi di atas menunjukkan bahwa sedekah bisa menjadi intrumen ampuh untuk meningkatkan kesejahteraan manusia yang tidak hanya mempunyai pendapatan tapi juga sehat. Kreteria tersebut sesuai dengan indikator kesejahteraan manusia atau Human Development Index (HDI). Dengan demikian sedekah bisa menjadi instrumen untuk meningkatkan kesejahteraan manusia (human welfare).

Proposisi minor yang berhasil dirumuskan dari fenomena perubahan perilaku informan setelah mengamalkan sedekah adalah. Pertama, "sedekah menjadi instrumen untuk meningkatkan kesejahteraan lahir dan batin melalui transmisi iman dan taqwa". Kedua, "sedekah menjadi intrumen meningkatkan kesejahteraan melalui transmisi perbaikan perilaku hidup informan terutama kejujuran, profesionalisme dan etos kerja 
tinggi”. Proposisi-proposisi di atas memberikan pelajaran: Pertama, memberikan pelajaran bahwa Allah-lah yang mempunyai hak mutlak siapa yang dikehendaki untuk sejahtera atau tidak dikehendaki untuk sejahtera. Namun kemutlakan itu direduksi oleh Allah sendiri, salah satunya melalui ibadah sedekah. Hal ini merupakan bentuk penghargaan yang luar biasa besarnya terhadap manusia. Manusia diberikan "mandataris" oleh Allah untuk menentukan kesejahteraannya sendiri melalui amalan sedekah.

Kedua, sedekah menjadi transmisi bagi manusia yang berfikir untuk merubah nasipnya melalui perbaikan prilaku hidup ke arah yang lebih baik, yaitu melaui kejujuran, profesionalisme, dan etos kerja. Ketiga perilaku hidup itu mengandung makna yang sangat dalam, jujur menunjukkan kita menjaga amanah yang diberikan orang lain kepada kita. Profesionalisme mengandung arti menggunakan potensi secara optimal yang kita miliki untuk kepentingan diri dan masyarakat. Hal itu menunjukkan bahwa orang yang profesional adalah orang menjaga amanah potensi manusia sebagai mahkluk paling sempurna yang diciptakan Allah. Etos kerja mengandung arti menggunakan waktu seefisien dan seefektif mungkin. Hal itu menunjukkan bahwa orang yang mempunyai etos kerja tinggi adalah orang yang menjaga amanah waktu yang diberikan oleh Allah kepada kita. Jadi itulah tiga bentuk perilaku hidup hasil didikan Allah dari amalan sedekah dan itulah tiga kata kunci yang bisa merubah nasib seseorang menuju kepada kesejahteraan hakiki.

Betapa tidak egoisnya Allah, betapa tidak arogannya Allah dalam menggunakan haknya dalam hal menentukan kesejahteraan manusia. Subhanallah, Allah hu Akbar, La Ila Ha Illauwah, pelajaran di atas menunjukkan bahwa sedekah mengantarkan kita untuk mengenal diri-Nya, mencintai-Nya dan menggantungkan hidup kepada diri-Nya. Kesadaran ketergantungan mutlak diri terhadap Allah itulah yang disebut dengan kesadaran spiritual (spiritual joerny). Kesadaran itulah yang mengantarkan manusia mencapai pada kesejahteraan hakiki (the riil welfare).

Atas dasar implikasi-implikasi proposisi-proposisi minor di atas yang mengkonstruk sedekah sebagai intrumen dari timbulnya: kesejahteraan sosial (social welfare), kesejahteraan yang berkelanjutan (sutainable welfare), kesejahteraan manusia (human welfare), dan kesejahteraan hakiki (the riil welfare), maka tidak berlebihan kiranya jika kami mengemukakan proposisi mayor dari hasil penelitian ini adalah sebagai berkut "Sedekah sebagai instrumen meningkatkan kesejahteaan hakiki dan paripurna". Hakiki 
adalah kesejahteraan yang diperoleh dengan cara membahagiakan orang lain, sedangkan paripurna adalah kesejahteraan lahir dan batin.

\section{KESIMPULAN DAN SARAN KESIMPULAN}

Berdasarkan hasil deskripsi dan pemaknaan terhadap fenomena sedekah yang dilakukan oleh informan, maka penelitian ini menemukan beberapa temuan yang dapat disimpulkan sebagai berikut. Pertama, amalan sedekah secara istiqomah yang dilakukan respoden dimotivasi oleh tiga kekuatan pendorong yaitu: (1) kekuatan emosional, yaitu perasaan merasakan kesediahan jika ada orang lain yang ada di sekitarnya merasa sedih atau susah; (2) kekuatan spritual, yaitu pemahaman informan terhadap konsep harta yang berkaitan dengan sumber dan pengeluaran. (3) kekuatan empik, informan merasakan lebih dimotivasi oleh pengalaman-pengalaman orang tua dan keluarga yang mendapatkan kesuksesan dan kebahagian hidup karena mengamalkan sedekah.

Kedua, setelah mengamalkan sedekah secara istiqomah informan merasakan bentuk balasan sedekah secara berbeda-beda, yaitu: (1) balasan sedekah dirasakan dalam bentuk kesehatan dan terhindar dari musibah; (2) balasan sedekah dirasakan dalam bentuk kesuksesan usaha dan tambahan penghasilan; (3) balasan sedekah bisa dirasakan dalam bentuk balasan 10 kali lipat bahkan lebih.

Ketiga, Dengan kebiasaan sedekah informan merasakan suatu perubahan kearah yang lebih positif didalam kehidupannya. Berdasarkan apa yang dirasakan informan, perubahan ke arah yang lebih positif dalam kehidupannya dapat dikelompokkan menjadi dua yaitu: (1) Sedekah meningkatkan ketaqwaan dan keimamanan kepada Allah. (2) Sedekah menghantarkan informan menuju pada perbaikan perilaku hidup seperti kejujuran, profesionalisme dan etos kerja tinggi.

Berdasarkan hasil pemaknaan terhadap fenomena sedekah yang dilakukan oleh informan dan perbandingan dengan teori serta fenomena empirik yang lain, maka penelitian ini menemukan beberapa temuan yang dapat berimplikasi terhadap konstruksi teori yang disimpulkan sebagai berikut: Pertama, melalui pemaknaan perilaku dan motivasi sedekah yang dilakukan informan, maka hasil penelitian ini memberikan kontribusi bahwa pola konsumsi rumah tangga tidak hanya dipengaruhi oleh 3 faktor yaitu ekonomi, sosial, dan budaya saja, namun ditambah satu faktor lagi yaitu faktor agama.

Kedua, Penelitian ini menemukan bahwa, fenomena pengalaman sedekah yang dilakukan informan memberikan pembuktian kepada kita, bahwa aktivitas sedekah atau 
mengkonsumsi barang/jasa untuk tidak dinikmati sendiri, tapi disebar untuk orang lain, maka konsumen tersebut tidak mengalami law of diminishing marginal utility.

Ketiga, balasan sedekah dirasakan dalam bentuk kesehatan dan terhindar dari musibah, kesehatan ini terbentuk karena perasaan si pemberi selalu senang dan tenang ketika bisa menyenangkan orang lain. Pemaknaan temuan ini perkuat oleh beberapa hasil penelitian antara lain: Allan Luks, Sandra Levy, David McClelland, James House, dan Stephen Post, dan hadist yang diriwayatkan oleh Anas bin Malik serta hadits yang diriwayatkan oleh Abu Hurairah. Temuan ini memberikan kontribusi sedekah bisa dijadikan sebagai konsep alternatif "asuransi kesehatan".

Keempat, balasan sedekah bisa dirasakan dalam bentuk kesuksesan usaha dan tambahan penghasilan. Temuan ini memberikan kontribusi sedekah bisa dijadikan sebagai konsep alternatif "asuransi musibah". Kelima, balasan sedekah dirasakan dalam bentuk balasan 10 kali lipat bahkan lebih, temuan ini memberikan kontribusi konsep sedekah bisa dijadikan sebagai wealth manager (manajer investasi) alternatif. Keenam, Sedekah melalui transmisi keimanan dan ketaqwaan bisa menjadi instrumen menuju kesejahteraan. Temuan ini memberikan kontribusi konsep sedekah bisa dijadikan sebagai instrumen kebijakan untuk meningkatkan kesejahteraan masyarakat. Ketujuh, Sedekah melalui transmisi perbaikan perilaku hidup seperti kejujuran, profesionalisme dan etos kerja tinggi bisa menjadi instrumen menuju sejahtera. Temuan ini memberikan kontribusi konsep sedekah bisa dijadikan sebagai instrumen kebijakan untuk meningkatkan kesejahteraan masyarakat.

\section{SARAN}

Berdasarakan implikasi sedekah sebagaimana yang telah dibahas pada bab sebekumnya, bahwa sedekah bisa berimplikasi pada pada empat bentuk kesejahteraan yaitu: kesejahteraan sosial (social welfare), kesejahteraan yang berkelanjutan (sutainable welfare), kesejahteraan individu atau manusia (human welfare), dan kesejahteraan hakiki/lahir dan batin (the riil welfare), maka sudah sewajarnya pemerintah sebagai penentu kebijakan memasukkan sedekah sebagai intrumen kebijakan praktis untuk meningkatkan kesejahteraan masyarakat. Instrumen tersebut bisa dimulai dari sebuah pencanangan program nasional yang berbentuk slogan seperti: "Gerakan Indonesia Bersedekah" atau "Gerakan Sedekah Menuju Sejahtera" 


\section{DAFTAR PUSTAKA}

Abidin Zainal, 2000, Filsafat Manusia: Memahami Manusia Melalui Filsafat, Bandung, Remaja Rosda Karya.

Abdullah, Taufik. 1991, Zakat Collection and Distribution in Indonesia, Mohammed Ariiff. The Islamic Voluntary Sector in South east Asia. Institute of Southeast Asian Studies. Singapura. Hal 50-84

Adiprigandani, Siti. 2005. Metode Penelitian Kualitatif. Diktat Workshop Metode Riset Kualitatif: Konsep dan Aplikasi. LSM Fakultas Ekonomi Universitas Indonesia, tidak dipublikasikan.

Ahmad Azhar Basyir, Garis-garis Besar Sistem Ekonomi Islam, Yogyakarta: BPFE, 1987

Ahmad, Sanep, Hairunnizam Wahid, dan Adnan Mohammed. 2005. Penswastaan Institusi Zakat dan Kesannnya Terhadap Pemabayaran secara Formal di Malaysia. Kumpulan Kajian ekonomi dan Kewangan Islam, Pusat Kajian Ekonomi UKM. Jurnal Penelitian.

Alwasilah, A. Chaedar. 2002. Pokoknya Kualitatif: Dasar-dasar Merancang dan Melakukan Penelitian Kualitatif. Pustaka Jaya. Jakarta.

Ali, Mohammad Daud. 1988. Sistem Ekonomi Islam: Zakat dan Wakaf. U1-Press. Jakarta

Aliasuddin. 2002, Zakat Atas Tabungan. Mon Mata, Jurnal Ilmu-ilmu Sosial Bidang Ekonomi Volume 4 No.2 Desember 2002. Penerbit Lembaga Penelitian Universitas Syiah Kuala Darussalam. Banda Aceh, Indonesia, Hal 89-100.

Al-Ba'ly, Abdul Al-Hamid Mahmud. 2006. Ekonomi Zakat: Sebuah KajianMoneter dan Keuangan Syariah. PT. RajaGrafindo Persada. Jakarta Hafidhuddin,

Alvin Y. SO Suwarsono,1991, Perubahan Sosial dan Pembangunan di Indonesia, LP3ES Jakarta.

Andimihardja, Kusnaka dan Hikmat, Harry. 2003. Participatory Research Appraisal: Ppengabdian dan Pemberdayaan Masyarakat, Bandung, Penerbit Humaniora.

Anonymous, 2003. Celebrating Indonesia: Fifty Years with the Ford Foundation 19532003. Ford Foundation. Jakarta.

Anselm Strauss, Juliet Corbin, 1990, Basic of Qualitative Research: Grounded Theory Proceduresand Techniques, London, New delhi, Sage Publication.

Ary Ginanjar A., 2001. ESQ, Rahasia Sukses Membangun Kecerdasan Emosi dan Spritual. Penerbit Arga, Jakarta

As-Syahatah, Husein. 2004. Akuntansi Zakat: Panduan Praktis Penghitungan Zakat Kontemporer. Pustaka Progressif. Jakarta

Badan Pusat Statistik (BPS). 2006, Statistik Indonesia, Jakarta.

Bahrom, Hasan, dan Mohd Sahnaz Saida, 2005. Kajian Terhadap Faktor Yang Mempengaruhi Pembayaran Zakat Perniagaan di Kalangan Usahawan: Kes Kajian Terengganu. Kumpulan Kajian Ekonomi dan Kewangan Islam. Pusat Kajian Ekonomi, UKM. Jurnal Penelitian.

Basrowi, Sudikin, 2002, Metode Penelitian Kualitatif Perspektif Mikro, Surabaya, Insan Cendikia.

Berger, L. Peter, Mary Douglas, Michell Foucoult, and Jurgen Harbermas, 1987, Cultural Analysis, London and New York: Routledge and Kegan Kegan Paul. 
Berger, L. Peter \& Thomas Luckmann, 1994, Tafsir Sosial Antar Kenyataan, terjemahan Hasan Basri dari The Social Construction of Reality: A Treatise in the Sociology of Knowledge, Jakarta: LP3ES.

Bossel, H. 1999. Indicators for Sustainable Development: Theory, Method, Application. International Institute for Sustainable Development. Manitoba.

Brox, O. 2006. The Political Economy of Rural Development: Modernization Without Centralization? Eburon Publisher. Delft.

Budi Handrianto. 2010. Sedekah, Hidup Menjadi Berkah dan Bahagia. Gema Insani. Jakarta.

Burhan Bungin, 2007, Penelitian Kualitatif: Komunikasi, Ekonomi, Kebijakan Publik, dan Ilmu Sosial Lainnya, Jakarta, Prenada Media Group. 2007, Metodologi Penelitian Kualitatif: Aktualisasi Metodologis ke Arah Ragam Varian Kontemporer, Jakarta, Raja Grafindo Persada.

Burhan, Umar. 2005. Perilaku Rumah Tangga Muslim dalam Menabung, Berinvestasi, dan Menyusun Portofolio Kekayaan dan Implikasinya Terhadap Perkembangan Bank Syariah. Disertasi Program Pascasarjana Universitas Brawijaya, Malang.

Campbell, Tom, 1994, Seven Theories of Human Society, alih bahasa Budi Hardiman, Tujuh Teori Sosial: Sketsa, Penilaian, dan Perbandingan, Yogyakarta: Kanisius.

Castro, C. J. 2004. Sustainable Development: Mainstream and Critical Perspectives. Organization and Environment, Vol. 17/2, pp. 195-225.

Chambers, Robert. 1987. Rural development: Putting the Last Fist, New York, Longman Scientific and Technical.

Chapra Umar, 2000, Islam dan Tantangan Ekonomi Islami Ekonomi, Cetakan Pertama, GIP dan Tazkia Institute, Jakarta.

Collin, Finn, 1997, Social Reality, USA and Canada: Routledge Simuktaneously Published

Colleta, Nat J dan Michelle LC. 2000. Violent Conflict and The Transformation of Social Capital. Washinton DC. World Bank.

Craib, Ian, 1986, Teori-teori Sosial Modern: Dari Parson sampai Habermas, Jakarta: Rajawali Press.

Damsar. 2002. Sosiologi Ekonomi. Edisi Revisi. Penerbit PT RajaGrafindo Persada. Jakarta.

Dasgupta, P. 1997. Social Capital and Economic Performance. Washinton DC. The World Bank.

de Haan, L. J. 2000, Globalization, Localization and Sustainable Livelihood, Sociologia Ruralis, Volume 40, Number 3, July 2000.

Dernburg F.Thomas. 1985. Macoreconomics: Concepts, Theories, and Policies. $7^{\text {th }}$ edition. McGraw - Hill, New York.

Dharmawan, A. H. 2000. Poverty, Powerlessness, and Poor People Empowerment: A Conceptual Analysis with Special Reference to the Case of Indonesia. Paper presented in the Workshop on Rural Institutional Empowerment held in the Indonesian Consulate General of the Republic of Indonesia in Frankfurt am Main Germany, August $26^{\text {th }} 2000$.

. 2006. Pendekatan-Pendekatan Pembangunan Pedesaan dan Pertanian:

Klasik dan Kontemporer. Makalah penulis yang disampaikan pada acara "Apresiasi Perencanaan Pembangunan Pertanian Daerah bagi Tenaga Pemandu Teknologi Mendukung Prima Tani”, diselenggarakan di Hotel Jaya-Raya, Cisarua Bogor, 19-25 November 2006.

Didin. 2002. Zakat dalam Perekonomian Modern. Gema Insani Press. Jakarta

Diulio, Eugene A., 1984. Teori Ekonomi Makro. Seri Buku Schaum; Teori dan Soal-soal. Penerbit Erlangga, Jakarta. 
Dove, Michael R (ed). 1985. Peranan Kebudayaan Tradisional Indonesia dalam Modernisasi. Yayasan Obor Indonesia, Jakarta.

Dube, S.C. 1988. Modernization and Development: The Search for Alternative Paradigms. Zed Books Ltd, London.

Edmund Husserl, "Phenomenology": The Encyclopaedia Britannica Article, Translated By Thomas Sheehan.

Elliot, J. A. 1996. An Introduction to Sustainable Development: The Developing World. Routledge. London and New York.

Ellis, F. 2000, Rural Livelihoods and Diversity in Developing Countries, Oxford University Press, New York.

Farrington, J. et. al. 1999. Sustainable Livelihoods in Practice : Early Applications of Concepts in Rural Areas'. ODI Natural Resources Perspectives. Number 42. June 1999. Overseas Development Institute. London.

Fear, F. A and Schwarzweller, H.K. 1985. Introduction: Rural Sociology, Community andCommunity Development, in Fear, F. A and Schwarzweller, H. K. (eds.). 1985. Research in Rural Sociology and Development, Focus on Community. JAI. Greenwich and London.

Feldman, Daniel C. dan Arnold, Hugh J. 1988. Managing Individual and Group Behavior in Organization, Tokyo, Mc Graw-Hill International Book Company.

Ferguson, Harvie, 2001, Phenomenology and Social Theory, dalam George Ritzer and Bary Smart, ed. Handbook of Social Theory, London, California, New Delhi: Sage Publications Ltd.

Firdausy, Carunia Mulya. 1997. "Pengembangan Potensi Ekonomi dan Pemberdayaan Ekonomi Rakyat di Biak Numfor, Irian Jaya, Jurnal Analisis CSIS, No.1, 67-76.

Fukuyama, F. 1997. Social Capital. George Mason University; Institute of Public Policy. Frank, A. G. 1978. Dependent Accumulation and Underdevelopment. Macmillan. London.

Friedman, John. 1991. Empowerment; The Politics of Alternative Development. Cambridge. Blackwell.

Galtung, J. 1995. On the Social Costs of Modernization: Social Disintegration, Atomie Anomie and Social Development . UNRISD. Geneva.

Gibson, James L. 1996, Organisasi (terjemahan), Jakarta, Penerbit Binarupa Aksara.

Gilarso, T. 1986., Ekonomi Indonesia; Sebuah Pengantar. Penerbit KANISIUS (anggota IKAPI), Yogyakarta.

Gonzales, J. et al. 2005. Participatory Research and Development for Sustainable Agriculture and Natural Resources Management a Sourcebook: Understanding Participatory Research and Development Vol. 1. CIP-UPWARD and IDRC. Los Banos.

Hacker, H. 1999. Empowerment Projects for and by Woman: Summary of Pilot Study. DED Yaounde. (Unpublished).

Hadiwijono, Harun, 1980, Sejarah Perkembangan Filsafat Barat, Yogyakarta, Kanisius.

Hardiman, F. Budi. 2003. Melampaui Positivisme dan Modernitas: Diskursus Filosofis tentang Metode Ilmiah dan Problem Modernitas. Penerbit Kanisius, Yogyakarta.

Halwani, R. Hendra. 1999. "Paradigma Baru Pembangunan: Pemberdayaan ekonomi Rakyat” Jurnal PSPP. Vol. II. No. 1, 49-64.

Hannesson, Rognvaldur. 1988. Ekonomi Perikanan (terjemahan), Jakarta, UI-Press.

Harmadi, Sonny Harry B. 2007. Pengangguran, Kemiskinan, dan Pertumbuhan Ekonomi di Indonesia , Jurnal warta Demografi, Tahun 37, No.3.

Hasan bin Ahmad Hamaban. 2010. Berobatlah Dengan Puasa dan Sedekah. Aqwam. Solo

Hendersond, James M., and Quandt, Richard E. 1980. Microeconomic Theory, A Mathematical Approach, Tokyo, McGraw Hill International Book. 
Hidayat, Herman. 1997. "Pemberdayaan Ekonomi Masyarakat", Jurnal analisis CSIS, Vol. $5,443-463$.

Hidayat, Zainul. 2007. Kemiskinan di Timor-Leste: Suatu Refleksi, Jurnal Analisis CSIS, Vol.5. 443-463

Ibnu Maskawih, 1985. Tahdib al-Akhlaq, Bairut: Dar-al Kutub al-Islamiyah,.

Ibrahim Fatih. A. 2007. Rahasia Dibalik Sedekah. Insan Kamil. Solo

Israel, Arturo. 1990. Pengembangan Kelembagaan; Pengalaman Proyek-Proyek Bank Dunia. Jakarta. LP3ES.

Immanuel Wallerstein. 1982, The Rise and Future Demise of World Capitalist System; Concepts for Comparative Analysis. in Hamza Alavi and Theodor Shanin. Introduction to The sociology of Developing Societies.

Kabeer, Nila. 1994. Reserved Realities: Gender Hierarchies in Development Thought, London, Verso.

Kanto, Sanggar. 2003. Sampling, Validitas dan Reliabilitas dalam Penelitian Kualitatif. Dalam Analisis Data Penelitian Kualitatif, Pemahaman Filosofis dan Metodologis ke Arah Penguasaan Model Aplikasi (Editor Burhan Bungin), Cetakan Pertama, hal 5163. PT RajaGrafindo Persada, Jakarta.

Killerby, Paul. Social Capital, Participation and Sustainable Development in International Community Development Conference on April 2003. Rotorda. New Zealand.

Khurshid Akhmad, 1992. Al-'Adl dalam Zainuddin Soedan dan Marryl WayDavier (edt.) Wajah-wajah Islam, Bandung: Mizan,.

Kuncoro, Mudrajad. 1997. Ekonomi Pembangunan, Yogyakarta, Penerbit AMP YKPM.

Lewis, Oscar. 1959. "Five Families: Maxican Case Studies in the Culture of Pverty" dalam Suparlan, Parsudi, 1996, Kemiskinan di Perkotaan, Jakarta, Penerbit Yayasan Obor Indonesia.

Maulani, Z. A. 2002, Zionisme: Gerakan Menaklukkan Dunia, Jakarta, Daseta.

Mannan, M A, 1997. Teori dan Praktek Ekonomi Islam, Edisi Terjemahan. Dana Bhakti Wakaf, Seri Ekonomi Islam No. 02. Edisi Lisensi, Yogyakarta.

Mankiw, Gregory N. 1997. Makroeconomics $4^{\text {th }}$ Edition. New York and Basingstoke by Worth Publishers.

, 2001, Teori Makro Ekonomi, Jakarta, Erlangga

2003. Makroeconomics $5^{\text {th }}$ Edition. New York and Basingstoke by Worth

Publishers.

Mangkunegara, A.A. Anwar Prabu. 2005. Evaluasi Kinerja SDM, Bandung, Penerbit PT. Refika Aditama.

Marten, G. G. 2001. Human Ecology: Basic Concepts for Sustainable Development. Earthscan. London and Sterling.

Martin, J. Paul. 2007. Religions nad International Poverty Alleviation: The Plusses and Minuses, Jurnal of International Affairs, Vol.61, Edisi I, 27-96.

Mohammad Miftahul Hidayat, 2000. "Teori Konsumsi Berorientasi Teologis Etis", Tesis, Yogyakarta: Magister Studi Islam UII,.

Moleong, Lexi J. 2001. Metode Penelitian Kualitatif. PT. Remaja Rosdakarya. Bandung.

Mubyarto. 1997. Pengentasan Kemiskinan Melalui Program IDT. Majalah Ilmiah Pangan, Vol.IX, No.34

Muhammad Abdul Mannan, 1997.Teori dan Praktek Ekonomi Islam, Yogyakarta: Dana Bhakti Wakaf,.

Muhammad Muhyidin. 2009. Keajaiban Shodaqoh. Diva Press. Yogyakarta.

Midgley, James. 1986. Community Participation, Social Development and The State. London. Metheun. 
Mufraini, Arif. 2006. Akuntansi dan Manajemen Zakat: Mengkomunikasikan Kesadaran dan Membangun Jaringan. Kencana. Jakarta

Muhadjir, Noeng. 2000. Metode Penelitian Kualitatif. Edisi IV. Rake Sarasin, Yogyakarta.

Muhammad Thobroni. 2008.Mukjizat Sedekah. Pustaka Marwa. Yogayakarta.

Mulyana, Deddy. 2002. Metodologi Penelitian Kualitatif. PT. Remaja Rosdakarya, Bandung.

Mulawarman, Aji Dedi. 2006. Menyibak Akuntansi Syariah. Kreasi Wacana. Yogyakarta

Mursyidi. 2003. Akuntansi Zakat Kontemporer. PT Remaja Rosdakarya Offset. Bandung

Narayan, D. 1999. Bonds and Bridges; Social Capital and Poverty. Washington DC. World Bank.

Natarajan, Tara. 2005. Agency of Development and Agents of Change: Localization, Resistance, and Empowerment, Jurnal of Economic Issues, Vol.39, Edisi 2, 409-419.

Nedler, David A dan Lawler III, Edward E. 1977. Motivation: Dianostic Approach, dalam Hachman, J. Richard. Perspective on Behavior in Organization, New York, McGrawHill International Book Company.

Nuruddid Muhammad Ali. 2006. Zakat Sebagai Konsumen Dalam Kebijakan Fiskal. PT. Raja Grafindo Persada. Jakarta

Nurkse, Ragnar. 1953. Problem of Capital Formation Underdevelopment Countries, dalam Kuncoro, Mudrajad, 1997, Ekonomi Pembangunan, Yokyakarta, Penerbit UPP-AMP YKPN.

Orleans, Myron, 2000, Phenomenology, dalam Kumpulan Bahan Mata Ajaran Metodologi Penelitian Kualitatif oleh Daniel T. Sparingga, FISIP Unair.

Osmani, S. R. 2000. Participatory Governance, People's Empowerment and Poverty Reduction. SEPED Conference Paper Series No. 7. UNDP. Washington, D.C.

Pearse, Andrew dan Michael Stiefel. 1979. Inequality into Partticipation: A Researdh Approaach, Genewa. UNRISD.

Peet, R and Hartwick, E. 1999. Theories of Development. Guilford. New York and London.

Prasetyo, Nunuk. 2003., Pola Konsumsi Lestari. Penerbit Sekretariat Pelayanan Tani dan Nelayan - Hari Pangan Sedunia (SPTN - HPS), http://www.sptn.or.id/article.php action.

Prathama, Rahardja \& Manurung Mandala. 2001. Teori Ekonomi Makro. Suatu Pengantar. Lembaga Penerbit FE - UI.

Prijono, OS dan AMW Pranarka. 1996. Pemberdayaan; Konsep, Kebijakan dan Implementasi. Jakarta. CSIS.

Purnomo, A. P. 2006. Strategi Nafkah Rumahtangga Desa Sekitar Hutan: Studi Kasus Desa Peserta PHBM (Pengelolaan Hutan Bersama Masyarakat) di Kabupaten Kuningan, Provinsi Jawa Barat. Thesis Magister. Program Studi Sosiologi Pedesaan Sekolah Pasca Sarjana. Institut Pertanian Bogor.

Raymond A. Morrow, 1994, Critical Theory and Methodology, London New Delhi, Sage Publications.

Reid, Ben. 2005. Poverty Alleviation and Participatory Development in the Philipines, Jurnal of Contemporary Asia, Vol.3, Edisi I, 29-53.

Rintuh, Cornelis dan Miar. 2005. Kelembagaan dan Ekonomi Rakyat, Yogyakarta, Badan Penerbit Fakultas Ekonomi UGM.

Robert. A. Denemark et al. 2000. World System History: The Social Science of Long Term Change. London. Routledge. 
Roxborough, I. 1994. Theories of Underdevelopment: Critical Social Studies. Macmillan. London.

Sahri Muhammad. 2006. Mekanisme Zakat dan Permodalan Masyarakat Miskin: Pengantar Untuk Rekonstruksi Kebijakan Pertumbuhan Ekonomi. Bahtera Press. Malang

Samuelson, Paul. A. \& Nordhaus, William. D. 2001, Macroeconomics, $17^{\text {th }}$ edition. By McGraw-Hill Companies, Inc. all rights reserved New York. Diterjemahkan oleh Gretta., et.al. Diterbitkan oleh P.T. Media Global Edukasi, Jakarta.

Sanapiah Faisal, 2003, Filosofi dan Akar Tradisi Penelitian Kualitatif, Jakarta, Raja Grafindo Persada.

Sanusi, Nur Azara, Norazlina Abd. Wahab, dan Nor Fadzlin Mohammad Bahar. 2005. Gelagat Kepatuhan zakat Pendapatan: Kajian Kes UKM. Kumpulan Kajian Ekonomi dan Kewangan Islam, Pusat Pengajian Ekonomi, UKM. Jurnal Penelitian.

Sayed Nawab Haidar Naqfi, 1985. Etika dan Ilmu Ekonomi, suatu Sintesis Islami, Bandung: Mizan,.

Sajogyo. 1982. Modernization Without Development. The Journal of Social Studies. Bacca, Bangladesh.

Setiadi, Nugroho J, 2003., Perilaku Konsumen; Konsep dan Implikasi untuk Strategi dan Penelitian Pemasaran. Penerbit Prenada Media, Jakarta.

Schneider, H. 1999. Participatory Governance: The Missing Link for Poverty Reduction. OECD Development Center, Policy Brief No. 17. Paris.

Schoorl, J.W. 1980. Modernisasi: Pengantar Sosiologi Pembangunan Negara-Negara Sedang Berkembang. PT. Gramedia, Jakarta.

Seligson, M. A and Passe-Smith, J.T. 2003. Development and Underdevelopment: The Political Economy of Global Inequality. Lynne Rienner. Boulder.

Setiadi, Nugroho J, 2003., Perilaku Konsumen; Konsep dan Implikasi untuk Strategi dan Penelitian Pemasaran. Penerbit Prenada Media, Jakarta.

Shahid, M. (2006). Review: Edmund Husserl: to think God, believing in God. Memorandum, 11,114-117.Retrieved//, from: http://www.fafich.ufmg.br/ memorandum/a11/shahid01.pdf

Sharp, Ansel M., Charles A. Register, and Paul W. Cerimes. 1996. Economics of Social Issues, Chicago, Richard D. Irwin.

Shepherd, A. 1998. Sustainable Rural Development. Macmillan. Basingstoke and London.

Snell, Scott A. and James, W. 1992. "Integrated Manufacturing and Human Resource Management: A Human Capital Perspective"., academy of Management review, Vol. 5, No. 3: 473.

Soerawidjaja, N. 2005., Berpikir Fungsional, Melawan Konsumerisme. Disajikan dalam Forum Diskusi FKB pada tanggal 30 Juli, Yogyakarta.

Solimun, 2002, Structural Equation Modelling (SEM) Lisrel dan AMOS, Penerbit Universitas Negeri Malang, Malang.

So, Y. A. 1990. Social Change and Development: Modernization, Dependency and WorldSystem Theories. Sage. Newbury Park, London and New Delhi.

Spencer, Herbert.1963. 'The Evolution of Societies'. Pp 9-13 in Etzioni, A. \& Halevy, Eva Etzioni- (eds). Social Changes: Sources, Patterns and Consequences. Basic Books, New York.

Subandi, 2009. Psikologi Dzikir, Studi Fenomena Pengalaman Transformasi Religius. Pustaka Pelajar. Yogyakarta.

Subiyanto, Ibnu. 1998. Metodologi Penelitian (Manajemen dan Akuntansi). Unit Penerbitan \& Percetakan Akademi Manajemen YKPN. Yogyakarta

Sudarsono, Heri. 2004. Bank dan Lembaga Keuangan Syariah. Ekonisia. Yogyakarta 
Sudjana, 1996, Teknik Analisis Regresi dan Korelasi Bagi Para Peneliti, Penerbit Tarsito, Bandung.

Suroso Imam Djazuli, 1999. Prinsip-prinsip Ekonomi Islam, Surabaya: Fak. Ekonomi UNAIR,

Sutikno, 2002, Filsafat Sebagai Dasar Pengembangan Ilmu Ekonomi, Jurnal Dimensi Ekonomi Edisi XXXIV/Tahun XIII/2002.

Syafa'at, Nizwar. 1997. Strategi Pengentsan Kemiskinan Pengelolaan Sumberdaya Alam DAS Hulu di Jawa, Jurnal Analisis CSIS, No. 4, 355-371.

Taylor Carman, 1999, The Body in Husserl and Merleau-Ponty, Philosophical Topics, VoL. 27, NO. 2, FALL 1999 Barnard College, Columbia University

Tim PPPA. 2009. Dahsyatnya Seekah. Zikrul Hakim. Jakarta.

Trisanti, Theresia. 1999. Strategi Pemberdayaan Ekonomi Kerakyatan Pada Saat Krisis Ekonomi, Jurnal Usahawan, No.08 Th.XXVIII, 24-28.

Triyuwono, Iwan dan M. As'udi. 2001. Akuntansi Syariah: Memformulasikan Konsep Laba dalam Konteks Metafora Zakat. Salemba Empat. Jakarta

Ulin, Priscilla R, Elizabeth T. Robinson, Elizabeth E. Tolley, Erin T. McNeill. 2002. Qualitative Methods; Applied Reseach in Sexual and Reproductive Health. Family Health International. North Carolina. USA.

Uphoff, Norman. 1986. Local Instutional Development; An Alatical Sourcebook. West Hartford. Kumarian Press.

Usman, P. 1995. Peran Sosiologi dalam Pengentasan Kemiskinan, Jakarta, Penerbit Galia Indonesia.

Usman, Sunyoto. 2003. Pembangunan dan Pemberdayaan Masyarakat, Yogyakarta. Pustaka Pelajar.

Varian, Hal. R., 1992. Intermediate Microeconomics, Third Edition. W. W. Norton \& Company. New York. London.

Wahid, Hairunnizam, Sanep Ahmad, dan Mohd Ali Noor. 2005, Kesadaran Membayar Zakat Pendapatan di Malaysia. Kumpulan Kajian Ekonomi dan Kewangan Islam. Pengajian ekonomi, UKM. Jurnal Penelitian.

Walizer, Michael H, Paul L. Wienir, 1986, Metode dan Analisis Penelitian, Terjemahan, Arief Sadiman dan Said Hutagaol, Penerbit Erlangga, Jakarta.

Wallerstein, I. 1976. A World-System Perspective on the Social Sciences. British Journal of Sociology, Vol. 2 7/3, pp. 343-352.

Wallerstein, I. 2005. World-Systems Anaylisis: An Introduction. 2nd printing. Duke University Press. Durham.

Warburton, D. 1998. Community and Sustainable Development: Participation in the Future. Earthscan. London.

Waters, Malcolm, 1994, Modern Sociological Theory, London, Thousand Oaks, London: Sage Publications.

Weissberg, R. 1999. The Politics of Empowerment. Praeger. Westport, Connecticut and London.

Widodo, Hertanto dan Kustiawan, Teten. 2001. Akuntansi dan Manajemen Keuangan untuk Organisasi Pengelola Zakat. Institut Manajemen Zakat. Ciputat 2005. Pedoman Akuntansi Organisasi Pengelola Zakat. Forum Zakat. Jakarta

.2004. Pedoman Zakat Praktis. Suara Muhammadiyah. Yogyakarta

. www.al-islam.com

www.pkpu.or.id

www.rumahzakat.or.id

www.ydsf.or.id 
Wilkinson, K. P. 1970. The Community as a Social Field. Social Force, Vol. 48/3, pp. 3 $11-322$.

Wilkinson, K. P. 1972. A Field-Theory Perspective for Community Development Research. Rural Sociology, Vol. 3 7/1, pp. 43-5

Wilopo, A. Siswanto. 1998. Dampak Resesi Ekonomi pada Penurunan Kematian dan Peningkatan Angka Harapan Hidup di Indonesia. Populasi. Volume 9 Nomor 1. PPK UGM. Yogyakarta.

Yustika, Ahmad Erani, 2006. Ekonomi Kelembagaan; Definisi, Teori dan Strategi. Penerbit Bayumedia. Malang.

Yusuf Mansur. 2008. The Miracle of Giving. Zikrul Hakim. Jakarta.

Yusuf Qardhawi, 1995. Peran Nilai dan Moral dalam Ekonomi Islam, Jakarta: Robbard Press,.

Zenrif, M. F., 2006, Realitas dan Metode Penelitian Sosial dalam Perspektif al-Qur'an, Malang, UIN Malang Press.

Zeitlin, Irving M., 1998, Memahami Kembali Sosiologi: Kritik Terhadap Teori Sosiologi Kontemporer, Yogyakarta: Gadjah Mada University Press. 